\title{
On Integrating Jewish Literature(s) into the Teaching of Early Modern Spanish Literature: Preliminary Thoughts
}

\section{Introductory remarks and rationale}

This brief paper focuses on a few methodological and practical challenges one faces when trying to introduce - or integrate - Jewish literature(s) into courses dedicated to modern, and especially early modern, Spanish literature. As a Hispanist, rather than a scholar of Jewish studies, my philological and pedagogic interests in Sephardic Jewry and its literary production are motivated first and foremost by the fact that they are yet another manifestation of Hispanic culture, which, alongside morisco culture and colonial culture, reflect on our concept of "Spanishness", and, consequently, on what we consider to be part of the Spanish literary canon.

I deem introductory courses to be the most appropriate context to expose students to the existence of Jewish works and their complex relation to Spanish literature. These courses are often students' first encounter with a literary canon both as an abstract - debatable - concept and as a corpus of texts, which they are expected to be familiar with by the end of the course. Thus, such courses are an opportunity to think with the students about the major questions and problems that would - hopefully - accompany them through their studies, and sometimes even beyond. At the same time, however, the time constraint imposed by the need to cover a relatively large amount of texts, approaches, and historical contexts, obliges us to modify our syllabi with caution.

My argument is that in order to integrate Jewish literatures into the narrative of courses introducing students with early modern Spanish literature, one does not need to radically change course syllabi nor dismantle the very canon of Golden Age literature. Rather, one needs to introduce minimal changes in the list of works studied - i.e., add one Jewish work, or selections thereof - and gesture, as one teaches other canonical works, towards the story of Hebrew, Jewish, and converso literatures - three different concepts with which students must be acquainted. The same holds, of course, for the Muslim cultural and literary heritage of the Iberian Peninsula and for the underrepresented morisco literature of the sixteenth century. Given, however, the focus of the present volume on Jewish and modern literatures, I will limit myself to Jewish and converso literature.

O OpenAccess. (C) 2020 Or Hasson, published by De Gruyter. (cc) BY-NC-ND This work is licensed under the Creative Commons Attribution-NonCommercial-NoDerivatives 4.0 License. 
Aiming to teach literature in a way that connects it to the historical, social, and political contexts in which it emerges, and upon which it often aims to act, I believe that any introduction to modern Spanish literature needs to address, at least in some capacity, three "big" questions, i.e., (1) what Spain is and how it came to be what it is; (2) who and what is considered Spanish, or what processes of homogenization and exclusion the forging this category entailed; and finally, (3), what geographic, linguistic, religious, and, ultimately, political criteria one uses when defining what Spanish literature is. As a pedagogical tool, I find it useful to briefly discuss in class examples demonstrating the tentative validity of each and every one of these criteria, and show students Hebrew and Arabic aljamiado texts - even without reading them, or reading a few lines of each as a defamiliarizing gesture indicating that Spanish literature can come in different alphabets and render itself legible (or illegible) do different groups.

\section{Jewish literature, Spanish literature, Diasporic literature}

Let us define "Jewish literature", at least for the sake of this discussion, as the literary production of authors who identify, or whose literary persona is identifiable as Jewish; and/or as a literature written for readers who identify, publically or in private, as Jewish; or, as a literature appropriated by such authors or readers. Let us define "Spanish literature" here, for the sake of the argument, as a literature written by, or for, authors and readers, respectively, who identify as Spanish; or, as a literature appropriated by such authors or readers. Using these narrow, sociological definitions, one could say - with the telling exception, perhaps, of Antonio Enríquez Gómez - that early modern, post-1492 Spanish literature which is also Jewish can be found mostly, if not exclusively, in the Western Sephardic diaspora, particularly in the works of ex-converso authors like João Pinto Delgado, Daniel Miguel Leví de Barrios, or Daniel Israel López Laguna, who had all left the Iberian Peninsula and embraced Judaism after spending a significant part of their life in Catholic contexts, and leading, at least publically, Christian lives.

There are, of course, many differences between the genres, topics, and styles that can be found in the heterogeneous corpus I am referring to here as the "Diasporic Spanish-Jewish literature". Yet as it has been shown by scholars who had studied different manifestations of this literary production (some of the most important ones published in this very volume), what is truly remarkable - especially given what we know about and what we expect from Jewish-Iberian literatures - 
is that the language, aesthetic models and literary codes employed in this corpus resemble general, i.e., non-Jewish, Siglo de Oro literature much more than they resemble the (mostly oral) literary and cultural production of the Jews expulsed from the Iberian Peninsula in 1492. In other words, these are works can be more easily described as "Spanish" than what we usually identify as "Sephardic" or "Judeo-Spanish".

\section{Center and periphery, tradition and rupture}

From a pedagogical perspective, it makes sense to include one representative work of this diasporic literature in survey course syllabi, as this corpus pushes further the boundaries of Golden Age literature. Just like, in the Muslim/Morisco case, allusions to Garcilaso or Lope de Vega found in an erotological treatise written in Tunisia show us that Spanish classics live beyond the boundaries of Christian Spain and of the Spanish Empire, so does the presence of baroque verse in Liturgical texts written in eighteenth-century Jamaica or dramatic forms such as the auto sacramental in the Western Sephardic diaspora helps us to better understand the reach of classical Iberian aesthetics. ${ }^{1}$ But like any boundary-pushing phenomenon, this literature - as fascinating and worthy of study as it is - is nevertheless a peripheral one, and should be taught in a manner that accounts for its marginality and reflects about it.

Furthermore, while this literature should be deemed "Jewish" in the aforementioned sense of the term, one must also account for the fact that (perhaps unlike other cases discussed in this volume), early modern Spanish-Jewish literature is not an organic continuation of an Iberian Jewish literary tradition, nor does it draw, at least not significantly, on what is referred to in the study of Hebrew literature as the Golden Age in Spain. Rather, it is a Jewish literature of "New Jews" (a term coined by Kaplan (1989), being a mirror-image of the Iberian concept of "New Christians"), a literature written by authors whose worldview, as shown by historians and literary scholars alike, had been forged in a Christian context, and whose access to the texts, literary forms, and principle language of Jewish creation in the Iberian Peninsula - Hebrew - was limited, to say the least.

1 On the morisco case, see López-Baralt 1992 (an abbreviated version of the argument in English can be found in López-Baralt 2018). For Jewish baroque verse and autos sacramentales, see, respectively, Fine 2011, and Davidi 2019. Davidi's study will also be of interest to students of comparative literature and Hebrew literature, as it shows the influence of this Golden Age in early modern drama. 
In that sense, it is peripheral not only from a Spanish perspective, but also from a Jewish one.

If this Jewish literature is an organic extension or continuation of another literature, it is, as Fine and others has shown in numerous occasions, a continuation of Iberian converso literature. ${ }^{2}$ There are two things that I believe are relevant for the framing of converso literature than need to be mentioned here. The first is that it cannot be considered "Jewish", certainly not in the strict, sociological sense of the term. ${ }^{3}$ The second, and this is, of course, relevant for thinking in practical terms of building course syllabi, is that converso literature is far from being a marginal phenomenon. One does not need to search in the periphery of Golden Age literature for texts that belong to this critical category. While texts such as Lazarillo de Tormes and Celestina both reflect an unequivocal consciousness of belonging to a minority (or, to be put in other terms, a sense of not belonging to mainstream, honorable society), these two works, which subvert the very postulates upon which modern Spanishness is premised - lineage, honor, Chrisitian orthodoxy, the ability to make sense of the world and find consolation in religious discourse, veneration for the Church and its institutions are, at the same time, as canonical as literary works can be.

\section{Towards an integrative narrative}

What needs to be integrated into the narrative of courses dealing with early modern Spanish literature is not merely the existence of a Jewish literature, in the narrow sense of the term, which is an extension of Spanish Golden Age literature, but rather that this particular Jewish literature reflects, on the one hand, a discontinuity with the long tradition of Hebrew literature in the Iberian Peninsula, and on the other, a continuity with the critical category of converso literature, to which various canonical works pertain. ${ }^{4}$

In practical terms, this means that one does not need to make radical changes in the list of texts taught in survey courses: by adding one representative work of the diaspora (e.g., López Laguna's Psalmos or one of Pinto Delgado's works) and re-contextualizing Lazarillo and Celestina, one can delineate, through relatively modest gestures, the story of ruptures and continuations between Hebrew literature, converso literature, and Jewish literature.

2 See, e.g., Fine 2011; Fine 2013.

3 Cf. the tentative, more cautious takes on the topic in Zepp 2014.

4 For a panoramic view and a theorization of this category, see Fine 2013. 
In the case of Lazarillo, it could be useful to read in class not only the canonical first part of the anonymous novel published in 1554, but also a few chapters from the neglected - and equally anonymous - Segunda Parte del Lazarillo, published in Antwerp in 1555. Although it circulated, at least in some editions, together with the first part, this sequel enjoyed very modest scholarly attention, and is rarely included in syllabi of introductory courses. In the sequel, the pícaro, under dire circumstances, suffers a metamorphosis from man to tuna fish, and struggles under his new identity to survive among the fish with all the doubts, fears, secrets and complexities such a challenge entails. Without imposing a reading of the Segunda Parte as a roman à clef depicting exclusively the forced conversion of the Jews, and without resolving the problem of authorship, this small addition to the study of the picaresque novel enables us to reconstruct one reading of the first Lazarillo, in which the picaro's otherness, skepticism, and heterodoxy are tied more explicitly to a forced, traumatic change of identity, secrecy, etc. ${ }^{5}$

In the case of Celestina, which, following Gilman's seminal study The Spain of Fernando de Rojas (1972) has become a paradigm of Spanish converso literature, a relatively modest addition to the curriculum - a reference to the early sixteenth-century Hebrew translation of the work, made by Joseph Tsarfati in Italy can significantly enrich both the discussion of the Tragicomedia's reception, and the narrative of the course as a whole. While the only extant part of this translation is the prefatory poem (available also in an English translation), ${ }^{6}$ the very existence of such a translation, and the stylistic aspects of the prefatory poem, which situate it within the Hebrew literary tradition of late-medieval Spain and Italy, provide grounds for a meaningful discussion in class regarding the unique encounter between (1) the work that marks, for many of us, the beginning of the Spanish Golden Age, (2) the possible appeal of Rojas's masterpiece to Jewish readers - who may or may have not been Sephardic -, and (3) the literary traditions of a Hebrew Golden Age, which, for the most part, are left out of the story.

5 For an integrative discussion of the 1554 Lazarillo vis-à-vis problem of conversion, see Zepp 2014: 72-92. On the Antwerp sequel and the problem of conversion, see Hasson 2014.

6 For the English translation, see Baron 2012. An edition of the Hebrew poem can be found in Cassuto 1935. For a stylistic analysis of the poem, see Baron \& Saguar García 2012. 


\section{Bibliography}

Anónimo, and Juan de Luna. Segunda Parte del Lazarillo. Ed. Pedro M. Piñero. Madrid: Cátedra, 1999.

Baron, Amy, and Amaranta Saguar García. "Historical and literary influences on Tsarfati's Poem composed by the Poet upon his translation of the tale of Melibea and Calisto." Celestinesca, 36 (2012): 9-34.

Baron, Amy. "English translation of A Poem Composed by the Poet upon his Translation of the Tale of Melibea and Calisto, Joseph ben Samuel Tsarfati, 1507." Celestinesca, 36 (2012): $35-46$.

Cassuto, Moshe David. "Me-Shirei Yosef ben Shmuel Zarfati: Ha-Komedia ha-Rishonah be-'Ivrit [The poetry of Joseph ben Samuel Tsarfati: the first comedy in Hebrew]." Jewish Studies in Memory of George A. Kohut 1874-1933. Eds. Salo Wittmayer Baron and Alexander Marx. New York: The Alexander Kohut Memorial Foundation, 1935. 121-128 [in Hebrew].

Davidi, Einat. "The corpus of Hebrew and Jewish autos sacramentales: Self-deception and conversion." European Journal of Jewish Studies 13 (2019): 182-226.

Fine, Ruth. "De la liturgia al relato testimonial: los Psalmos de David de Daniel Israel López Laguna." Calíope 17.1 (2011): 177-197.

Fine, Ruth. "La literatura de conversos después de 1492: autores y obras en busca de un discurso crítico." Lo converso: orden imaginario y realidad en la cultura española. Eds. Ruth Fine, Michèle Guillemont, and Juan Diego Vila. Madrid: Iberoamericana/Vervuert, 2013. 499-526.

Gilman, Stephen. The Spain of Fernando de Rojas: The Intellectual and Social Landscape of “La Celestina”. Princeton: Princeton University Press, 1972.

Hasson, Or. "Hacia una lectura de la conversión en la Segunda Parte del Lazarillo (Amberes, 1555)." eHumanista/Conversos, 2 (2014): 94-106.

Kaplan, Yosef. From Christianity to Judaism: The Story of Isaac Orobio de Castro. Oxford: Oxford University Press, 1989.

López-Baralt, Luce. "A Spanish Kāma Sūtra: The First Erotic Treatise in the Spanish Language.” Eros, Family and Community. Eds. Ruth Fine, Yosef Kaplan, Shimrit Peled, and Yoav Rinon. Hildsheim: Georg Olms, 2018. 115-129.

López-Baralt, Luce. Un Kama Sutra español, Madrid: Siruela, 1992.

Zepp, Susanne. An Early Self: Jewish Belonging in Romance Literature, 1499-1627. Stanford: Stanford University Press, 2014. 